\title{
AN ASSESSMENT OF BIAS AND FAIRNESS OF THE CULTURE ASSESSMENT INSTRUMENT
}

\author{
THEMBA JAMES NKOSI \\ GERT ROODT \\ Department of Human Resources Management \\ Rand Afrikaans University
}

\begin{abstract}
The aim of this study was to investigate the bias and fairness of the Culture Assessment Instrument (CAI), that is, to assess whether the mean culture scores of different groups (race, gender, age and language) discriminate on a total score and an item level. The sample consisted of 4066 respondents from five different companies, originating from various industries. The scores of the $56 \mathrm{CAI}$-items were factor analysed on two levels, followed by an iterative item analyses. Significant differences between race and language mean scores were identified on a total score and item level. Where differences on an item level were detected, such item-wordings were scrutinized to ensure that they were fair, non-prejudiced and not stereotyping any group. Based on these findings, it was concluded that the CAI in its current form is not biased against any particular group and is therefore fair.
\end{abstract}

\section{OPSOMMING}

Die doel van hierdie studie was om die sydigheid en billikheid van die Culture Assessment Instrument (CAI) te ondersoek, dit is om te bepaal of gemiddelde kultuurtellings van verskillende groepe (ras, geslag, ouderdom en taal) diskrimineer op 'n totaaltelling en itemvlak. Die steekproef het bestaan uit 4066 respondente uit vyf verskillende organisasies, afkomstig uit verskillende bedrywe. Die tellings van die 56 CAI-items is op twee vlakke gefaktoranaliseer, gevolg deur 'n iteratiewe itemontleding. Beduidende verskille tussen gemiddelde tellings van rasen taalgroepe is identifiseer, maar slegs 'n klein proporsie van die variansie kon aan kultuurverskille toegeskryf word. In gevalle waar verskille op itemvlak geïdentifiseer is, is sulke item-bewoordings ondersoek vir billikheid bevooroordeling en die nie-stereotipering van enige groep. Gebaseer op hierdie bevindinge, is daar tot die gevolgtrekking gekom dat die CAI in sy huidige vorm nie sydig teenoor enige groep is nie en gevolglik billik is.

\begin{abstract}
Motivation for the study
The changes in South Africa after 1994 had an impact on South African organisations in relation to the challenging economic conditions and political imperative. This led to the focus on employees as a source of competitive advantage and the emphasis on organisational culture (which has been established to be having a high impact on the bottom-line business results), as a means to mobilise employees for productivity and profit.
\end{abstract}

It is imperative for management to know the company culture and assess employees' belief system against the organisation's values. The diversity of the South African population, with its variety of cultures, led to a need for a valid, reliable, unbiased, and fair culture assessment instrument. The requirement is that such measuring instrument should respect cultural diversity and make accurate predictions of members of, amongst others, different race, gender, age and language groups.

\section{Organisational culture}

There is no single universally accepted definition of the term "Organisational culture" and this has led to a great deal of confusion and ambiguity in the literature. Organisational culture is often defined in terms of shared meanings-patterns of beliefs, rituals, symbols, and myths that evolve over time, serving to reduce human variability and control and shape employee behaviour in organisations (Peters \& Waterman, 1982; Wilkins \& Ouchi, 1983; Denison, 1996).

The development of culture is a natural socio-dynamic process, which occurs regardless of the intent of executive management, although it may be influenced by management (Schein, 1985). While organisation may develop a relatively homogeneous culture (Peters \& Waterman, 1982), unique and divergent subcultures may evolve for separate departments or sub-groups within the organisation. Other theories have demonstrated an appreciation for the function of culture as social glue.

Requests for copies should be addressed to: TJ Nkosi, Department of Human

Resource Management, RAU, PO Box 524, Auckland Park, 2006
According to Smircich (1983), culture conveyed to employees a sense of identity, facilitated the generation of commitment to something larger than the self, and enhanced social system stability, as well as guiding and shaping behaviour.

Martins' (1989) Culture Assessment Instrument represented one line of inquiry in the field of organisational culture. Martins (1989, p.45) defined organisational culture as follows: "Organisational culture is an integrated pattern of human behaviour, which is unique to a particular organisation and which originated as a result of the organisation's survival processes and interaction with its environment. Culture directs the organisation to goal attainment. Newly appointed employees must be taught what is regarded as the correct way of behaving".

Culture provides an underlying pattern to the behaviour of organisations, just as personality provides an underlying pattern to the behaviour of the individual. A strong culture provides employees with a clear understanding of "the way things are done". It provides stability to an organisation, the community, and South Africa as a nation (Martins \& Martins, 2002).

Groeschl and Doherty (2000) pointed out that culture consists of several elements of which some are implicit and others are explicit. Schein (1985) identified three levels of culture, i.e. artefacts, values and assumptions (see Figure 1). Insight into these levels is fundamental to understanding the culture of organisations.

In order to fully understand the complexity of the organisational culture literature, it is necessary to explore the various perspectives of culture that have been adopted by the organisational behaviourists and other researchers in this field (Wilson, 2001). Martin and Meyerson (1988) identified the following three major perspectives in organisational culture research.

The integration perspective portrays a strong or desirable culture as one where there is organisation-wide consensus and consistency. Espoused values are consistent with formal 
practices, which are consistent with informal beliefs, norms and attitudes. Cultural members share the same values, promoting a shared sense of loyalty and commitment. Where inconsistencies, conflict or subcultural differentiation occur, this is portrayed as being a weak or negative culture (Martin, 1995).

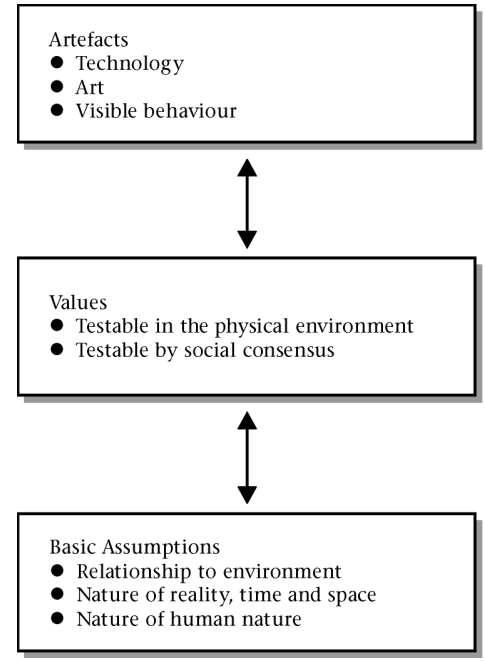

Visible but often not understood

Figure 1: Schein's levels of culture (Source: Adapted from Schein, 1985, p. 14)

The differentiation perspective emphasises that rather than consensus being organisation-wide, it only occurs within the boundaries of a subculture. At the organisational level, differentiated subcultures may co-exist in harmony, conflict or indifference to each other. Van Maanen (1991), in his study of Disneyland, found groups of employees who considered themselves as being distinct. These sub-cultures related to different jobs, different levels of organisational status gender and class. Claims of harmony from management masked a range of inconsistencies and group antagonisms. What is unique about a given organisation's culture, then, is the particular mix of subcultural differences within an organisation's boundaries.

The fragmentation perspective views ambiguity as the norm, with consensus and dissension co-existing in a constantly fluctuating pattern influenced by events and specific areas of decision making. As stated by Frost et al. (1991), consensus fails to coalesce on an organisation-wide or subcultural basis, except in transient, issue-specific ways. Rather than the clear unity of the integration perspective, or the clear conflicts of the differentiation viewpoint, fragmentation focuses on that which is unclear.

Many of the studies in organisational culture focus on only one of these perspectives, arguing whether it and it alone is evident within the organisation. As an example of this, Meyerson (1991) have made the point that much of the popular literature (Deal \& Kennedy, 1982; Peters \& Waterman, 1982) rested on the mistaken assumption that organisational culture consists of shared meanings and commonalties that are quite homogeneous, monolithic and organisation-wide. Little or no consideration was given to the potential existence of subcultures or dissension unless as an indication of a weak culture.

There are also major methodological differences between the three perspectives. Martin and Meyerson (1988) argued that any culture contains elements that can be understood only when all three perspectives are used. From a senior manager's/director's point of view, the integrationist perspective may be congruent with a manager's desire to see their values and policies shared and followed. Middle management may want to distance itself from senior management and therefore subcultures and a differentiation perspective may be more appropriate. Newcomers and disenchanted shop floor workers may fit in more with the fragmentation perspective.
Therefore, within a company there may be organisation-wide consensus on some issues, consensus only within certain subcultures on other issues and an ambiguous state on the remainder. Schein, in Frost et al. (1991), suggested that there may be a core set of ideological guidelines within an organisation that require a minimal consensus and consistency, otherwise organisations would not function.

Therefore consistency, consensus, harmony and integration may occur, but within the midst of inconsistencies, ambiguities, conflicts, disruption and dissolution. This complexity can cause a major headache. Following is a description of various models of organisational culture.

\section{Measuring Organisational Culture}

Although the concept of organisational culture has been prominent in organisational and management literature since the 1970s (Barley, Meyer, \& Gash, 1988), scholars still disagree on the best way to measure it (see O'Reilly, Chatman, \& Caldwell, 1991; Rousseau, 1990a). Some writers have suggested the use of multiple methods (e.g., Martin, 1992; Rousseau, 1990a), but these methods are often complex, expensive, and timeconsuming (Ashkanasy et al., 2000a).

The literature since 1989 on the study, diagnosis and measurement of culture has not been particularly abundant. Perhaps this is because there has been so much emphasis on the characteristics of a "quality" culture that managers are no longer concerned about the kind of culture they have; but only about the kind of culture they want to have (Lewis, 1995).

Reynierse and Harker (1986) use a combination of quantitative and qualitative measures to measure culture. The qualitative methods involve interviews and group discussions, while the quantitative method, which they call organisational dynamics, is a survey questionnaire using 95 items on a five-point ordinal scale of definite agreement to definite disagreement. The method aims to provide managers with tangible feedback in managing culture, their "fundamental proposition" being "that you can't manage organisational culture unless you can measure it" (Reynierse \& Harker, 1986, p. 1).

Reynolds (1986) used a questionnaire to measure culture differences between organisations to see if the measured differences relate to differences in performance.

Barnett (1988) outlined details of what he calls a "Galileo tm" or "Galileo analysis" for measuring culture accurately. Some of the methods are common to those used in qualitative approaches, but Barnett quantifies the results. It is considered that the method is too narrow, using only language, symbols and concepts as measurable elements.

Wiener (1988) measured "central value systems" and believes that by measuring the intensity and breadth of key values, one can measure culture.

Nossiter and Biberman (1990, p.13) have used a technique for studying and diagnosing culture they call "projective drawing and metaphorical analogy fantasising", where questionnaires ask participants to draw an image and name an animal representing their organisation and department. They believe that the creativity involved may motivate employees to think more about their organisations.

Tucker et al. (1990) designed a comprehensive questionnaire, developed from interviews and discussions with 50 managers of organisations. They believe results from the questionnaire, which are quantified, will help provide some preliminary information on the organisation's culture to managers attempting to deal with particular situations and problems with their cultures. 
Gabriel (1991) saw stories as the basis for the myths that act as coping mechanisms for individuals in organisations. Most of these techniques are as yet too recent for much empirical testing to have been carried out on them.

\section{A case for Quantitative Measurement}

Among authors who suggested some use of quantitative measures are Amsa (1986), Barnett (1988); Bookbinder (1984); Cooke and Rousseau (1988); Desatnick (1986); Hofstede (1986); Reynierse (1986); Reynierse and Harker (1986); Reynolds (1986) and Wiener (1988). What is borne out by the literature is that questionnaires can play an important role in the quantitative analysis of organisational culture (Reichers \& Schneider, 1960; Rousseau, 1990a).

Scholars such as Martin (1992) have noted that quantitative assessment of organisational culture has been criticized in the past because of a strong mono-method bias in the field. Although Martin argues for a need to include qualitative data in culture studies, the essence of her case is that there is a need for a multilevel and multimethod conceptualization. In this respect, Schein's (1985) three level typology provides a distinctive role for both quantitative and qualitative measurement.

Further, as the element of culture become more conscious and observable to participants in a study, they become more accessible to standardized assessment (Rousseau, 1990a). For example, it is generally agreed that surveys represent an efficient and standardized means of tapping the shallower levels of Schein's typology.

The deepest level of culture, on the other hand, can be investigated only through more intensive observation, focused interviews, and the involvement of organisational members in self-analysis (Ott, 1989; Rousseau, 1990a; Schein, 1990). The thrust of this argument is that there is a clear and continuing role for quantitative measures as a means of assessing the less abstract levels of organisational culture.

All quantitative measures of culture are likely to suffer from the same limitations, with the main weakness being that basic assumptions are often non-debatable and unconscious. People's written or oral answers to questions are not necessarily indicative of their basic assumptions.

The usefulness of quantitative measurement may not be restricted to the shallower levels of organisational culture only. Deal and Kennedy (1982) have argued, there may be grounds for maintaining that the three levels of culture are unified especially when a culture may have the potential to tap deeper levels of culture (Ott, 1989; Rentsch, 1990).

Ashkanasy et al. (2000a) have noted that survey methods have characteristics that render them especially useful for organisational culture research. Self-report surveys allow respondents to record their own perceptions of reality. Because behaviour and attitudes are determined not by objective reality but by actors' perceptions of reality (Rentsch, 1990), it is clearly appropriate to focus on perceptions rather than reality. Further, self-report measures offer internal credibility to organisational members, which is likely to increase the likelihood that members will accept the results of the survey.

Researchers have cited numerous other advantages of survey assessment and of quantitative techniques generally. These include allowing replication and cross-sectional comparative studies, providing an accepted frame of reference for interpreting data, helping the evaluation and initiation of culture change efforts in organisations, and providing data that can be analysed through multivariate statistical techniques (Cooke \& Rousseau, 1988; Xenikou \& Furnham, 1996).
In summary, what is borne out by the literature, is that questionnaires can play an important role in the quantitative analysis of organisational culture (Reichers \& Schneider, 1990).

\section{A need for assessing for bias and fairness of Culture} Assessment Instrument

The purpose of the current study is to establish if the Culture Assessment Instrument of Martins (1989) has the ability to validly and reliably, measure with fairness and without bias the culture mean scores of the different race, gender, age and language groups. The assumption was made that if culture measuring instruments are biased and unfair towards any particular group, it may negatively affect the measuring outcomes.

The diversity of the South African population, with its variety of cultures, led to a need for valid, reliable, biased free and fair culture assessment instrument. The requirement is that such measuring instrument should respect cultural diversity and make accurate predictions of members of different race, gender, age and language groups. Such reliable instrument can provide valuable insight into the culture of a company represented by a heterogeneous workforce.

Obtained differences should not be attributed to subjective content of the items i.e. a response to a stereotypical statement, but on the objective assessment of 'reality' to be measured.

In the field of tests and measurements the word unfairness or inequity means anything bad, bigoted, racist or suppressive thus, a subjective perception or opinion. Fairness is the focus on the accusation that tests or measurements are unfair, contaminated by extraneous factors, and subject to misuse and abuse.

The term bias is defined as a systematic error in the measurement process and is also referred to as differential item functioning (DIF) (Kanjee, 2002). The term is conceptually distinct and operationally different from the concept of fairness, equality, and prejudice.

Bias then is a technical term and denotes nothing more or less than the consistent distortion of a statistics (Osterlind, 1983, p.10). Bias as stated by Osterlind (1983), is also considered the presence of a systematic error in measurement. Items are judged relatively more or less difficult for a particular subgroup by comparison with the performance of another subgroup or groups drawn from the same population.

People respond to questionnaires on the basis of their response sets, in cross-cultural research, therefore, some problems arise because societal cultures often differ in their response sets on the basis of which people respond to questionnaires (Hui \& Triandis, 1989; Triandis, 1994).

The transferability of the studies to other cultures was identified by Elenkov (1998) as one of the biggest obstacles in crosscultural research. Individuals come from different cultural groups, which also affects their mindset and framework and they would therefore interpret stimuli in different ways. This variance in interpretation could have a significant influence on the results.

Berry and Triandis (1980) argued that it should be possible to compare two groups on a single dimension, where they have a common feature or equivalence. The two authors identified the following kinds of equivalence:

- Functional equivalence, exists when two or more behaviours related to functionally similar problems;

- Conceptual equivalence, lie in the common meaning of stimuli concepts or behaviours and is also a pre-condition for comparison;

- Translation equivalence, is of importance where the existing research instrument is translated by using a bilingual 
translator, i.e. translation to a new language and then reverses the translation into the original language;

- Semantic equivalence, uses a bipolar adjective scale to indicate the meaning of a concept across languages; and

- Metric equivalence, essentially means the structuring of the measuring instrument in similar ways within one group in order to make valuable inter-group comparison.

All of the above mentioned equivalences need to be present in order for the measuring instrument to have construct validity.

The following section deals with the research design of the study

\section{METHOD}

The research participants

The sample consisted of 4066 participants from five different companies originating from various industries. Particulars of organisations that are included in the study are provided in Table 1. From Table 1 it is clear that there are significant differences in sample size (ranging from 119 to 2459) between the different organisations. Noting that sample size effects levels of significance, due consideration was given to it during the analysis phase.

TABLE 1

Participating Organisations

\begin{tabular}{|c|c|c|}
\hline Company No. & Organisation & $\mathbf{N}$ \\
\hline 1 & Bank & \\
\hline \multicolumn{3}{|l|}{1056} \\
\hline 2 & Bank-Home Loans & 219 \\
\hline 3 & Retail & 119 \\
\hline 4 & Information Technology & 213 \\
\hline 5 & Services-Parastatal & 2459 \\
\hline Total & & 4066 \\
\hline
\end{tabular}

Table 2 provides a brief overview of the biographical properties of the survey sample. From Table 2 it can be inferred that the majority of respondents are white, male, Afrikaans speaking and in the age group 24-35.

\section{The measuring instrument}

The measuring instrument (CAI) was developed by Martins (1989). The latest version of the CAI consists of 89 items, but only 56 items, that were common to all the companies in the sample, were included in the study. These 56 items are proportionally representative of the six dimensions of the questionnaire. The overall reliability (Cronbach Coefficient Alpha) of the five-point response scale version of the instrument, used in this study, is 0,945 . The internal consistency of the dimensions varies between 0,655 and 0,932 .

The theoretical model that underpins the Culture Assessment Instrument of Martins (1989) is provided in Figure 2. The model consists of three main elements, i.e. the organisational system, survival functions and dimensions of culture. The various subsystems together form the culture of the organisation, which influences the behaviour of employees, suppliers and customers as well as the relationship with the community.

According to Martins (1989) an organisation is a complex social system in which individual and group activities take place. In order for the organisation to adapt to the external environment its internal processes also have to change and adapt on a continuous basis.
The organisational system consists of five systems i.e., goal, technical, structural, psychosocial, and management subsystem. These five subsystems form the internal subsystem. The external subsystem consists of the environment in which the organisation operates. The way, in which all the external factors are dealt with, could have a major impact on the success and survival of the organisation.

TABLE 2

Biographical Variables

\begin{tabular}{|c|c|c|}
\hline Category & Count & $\%$ \\
\hline \multicolumn{3}{|l|}{ Race } \\
\hline White & 1086 & 26,71 \\
\hline Coloured & 294 & 7,23 \\
\hline Indian & 125 & 3,07 \\
\hline Black & 912 & 22,43 \\
\hline No response & 1649 & 40,56 \\
\hline Total & 4066 & 100 \\
\hline \multicolumn{3}{|l|}{ Age } \\
\hline 24 and younger & 438 & 10,77 \\
\hline 25-35 & 1808 & 44,47 \\
\hline $36-45$ & 1006 & 24,74 \\
\hline 46 and more & 638 & 15,69 \\
\hline No response & 176 & 4,33 \\
\hline Total & 4066 & 100 \\
\hline \multicolumn{3}{|l|}{ Gender } \\
\hline Male & 2034 & 50,02 \\
\hline Female & 1876 & 46,14 \\
\hline No response & 176 & 3,84 \\
\hline Total & 4066 & 100 \\
\hline \multicolumn{3}{|l|}{ Language } \\
\hline Afrikaans & 1014 & 24,94 \\
\hline English & 225 & 5,53 \\
\hline Other & 21 & 0,52 \\
\hline No response & 2806 & 69,01 \\
\hline Total & 4066 & 100 \\
\hline
\end{tabular}

It is therefore assumed that as a result of the interaction and reciprocal influence of the various subsystems on one another, a unique culture is created in each organisation, which makes it unique and distinguishes it from other organisations.

The research procedure

The data set was built from data gathered from the participating companies over the past few years. The information was gathered mainly with a view to improve the performance of the companies. Hence, the aim in gathering the information was the same in all the cases.

\section{Statistical analysis}

The statistical procedures applied were selected for their suitability to test the research hypothesis of the study. In the first phase of the study procedures applied include descriptive statistics, factor analyses, and iterative item analyses to establish the reliability of the construct being used.

In respect of factor analyses, a procedure developed by Schepers (1992) was followed. This procedure includes first as well as second level factor analyses. In the second phase of the data analyses, analyses of variance and a measure of association was applied to test for differences between the mentioned groups.

The statistical consultations service of the Rand Afrikaans University conducted the analyses. All calculations were done by means of SPSS-Windows program of SPSS-International. 


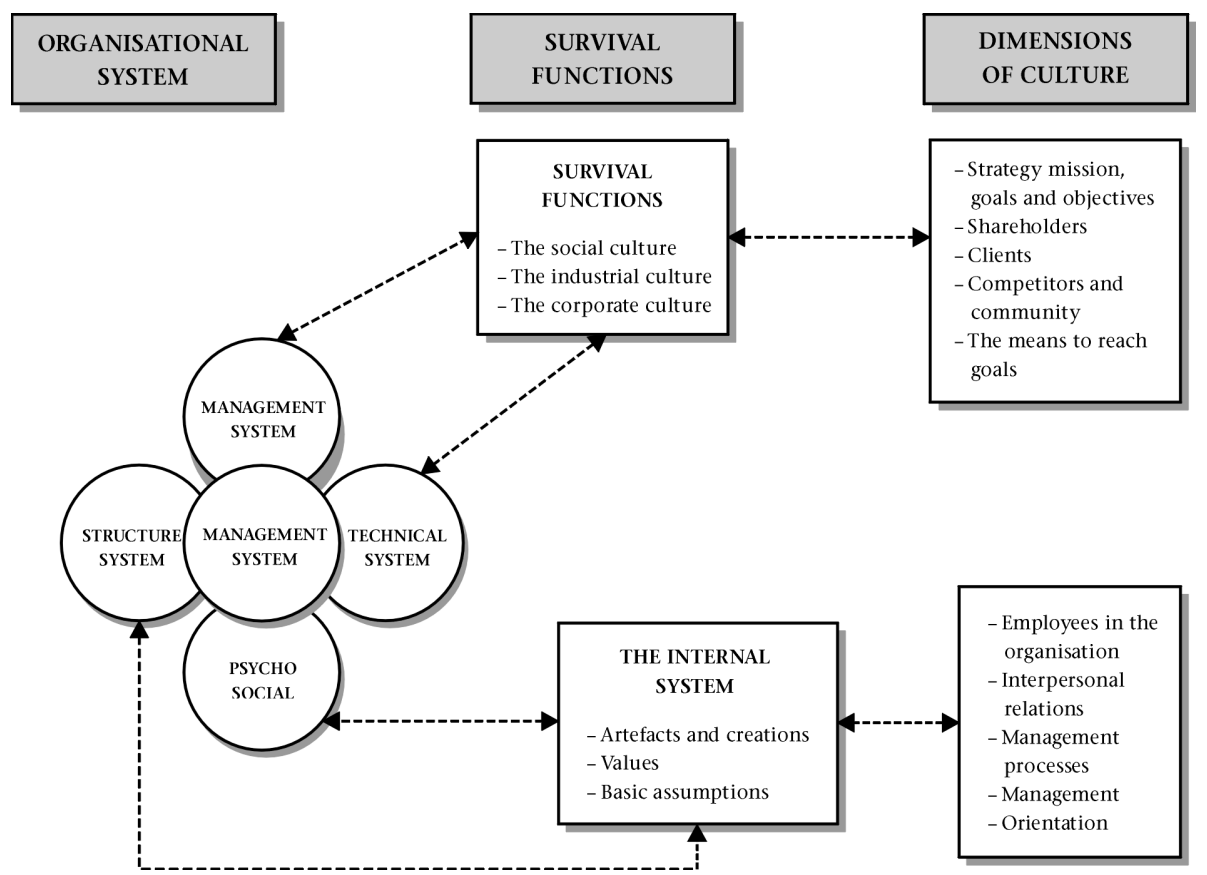

Figure 2: Martin's Model of Culture

Source (Martins, 1989, p. 92)

\section{RESULTS}

The analyses of the data proceeded in two phases.

Phase 1: Factor and reliability analyses

The item scores on the CAI were factor analysed in order to determine the underlying factor structure of the Instrument. A procedure developed by Schepers (1992) was followed in order to counter for possible effects of differential item skewness resulting in artefactors (artificial factors). Also this procedure normalises the distributions through the creation of sub-scores that are more suitable for factor analysis.

First Level Factor Analysis

In order to determine sampling adequacy and test for sphericity, the Kaiser-Meyer-Olkin Measure of Sampling Adequacy $(0,971)$ and the Bartlett's Test of Sphericity (Chi square $=73746,998, \mathrm{df}=$ $1540 ; p=0,000)$ were respectively carried out on the intercorrelation matrix of the 56 items of the instrument. The obtained results indicated that the matrix complies with the requirements for factor analysis.

The 56 items of the CAI were intercorrelated and the eigenvalues of the unreduced intercorrelation matrix were calculated. Owing to limited space, the intercorrelation matrix $(56 \times 56)$ is not reproduced here. Nine factors were postulated according to Kaiser's (1974) (eigenvalues-greater-than-one) criterion. The eigenvalues of the unreduced item intercorrelation matrix are given in Table 3.

The factor matrix was rotated to simple structure by means of Varimax rotation (see Table 4). From Table 4 it can be seen that only eight factors were extracted. No significant loadings were obtained on the ninth factor. The eight factors explain about $46 \%$ of the variance in the factor space. It can also be seen from Table 4 that factors 7 and 8 each have only two item loadings, which make them non-determined. It is pointed out that a factor should consist of at least three item loadings. These two factors were retained for the second level factor analysis.

The distribution statistics of sub-scores on the eight factors are depicted in Table 5 . An inspection of Table 5 reveals that this distribution is rather symmetric and closely resembles a normal distribution, based on the close proximity of the mean, median and mode. The distributions are thus suitable for analysis of variance, complying with a major requirement according to Hair et al. (1998).

TABLE 3

EIGENVALUES OF THE UNREDUCED ITEM INTERCORRELATION MATRIX

\begin{tabular}{|c|c|c|c|c|c|}
\hline Root & Eigenvalues & $\begin{array}{l}\text { Cumulative } \\
\text { Variance \% }\end{array}$ & Root & Eigenvalues & $\begin{array}{l}\text { Cumulative } \\
\text { Variance \% }\end{array}$ \\
\hline 1 & 14,668 & 26,193 & 29 & 0,642 & 75,607 \\
\hline 2 & 2,714 & 31,040 & 30 & 0,623 & 76,720 \\
\hline 3 & 1,806 & 34,266 & 31 & 0,616 & 77,821 \\
\hline 4 & 1,595 & 37,115 & 32 & 0,598 & 78,889 \\
\hline 5 & 1,345 & 39,517 & 33 & 0,594 & 79,950 \\
\hline 6 & 1,264 & 41,774 & 34 & 0,590 & 81,003 \\
\hline 7 & 1,145 & 43,819 & 35 & 0,580 & 82,039 \\
\hline 8 & 1,136 & 45,848 & 36 & 0,568 & 83,054 \\
\hline 9 & 1,059 & 47,739 & 37 & 0,561 & 84,055 \\
\hline 10 & 0,989 & 49,506 & 38 & 0,556 & 85,049 \\
\hline 11 & 0,947 & 51,198 & 39 & 0,545 & 86,022 \\
\hline 12 & 0,912 & 52,827 & 40 & 0,543 & 86,991 \\
\hline 13 & 0,887 & 54,410 & 41 & 0,533 & 87,942 \\
\hline 14 & 0,872 & 55,968 & 42 & 0,517 & 88,865 \\
\hline 15 & 0,828 & 57,447 & 43 & 0,511 & 89,778 \\
\hline 16 & 0,823 & 58,916 & 44 & 0,503 & 90,677 \\
\hline 17 & 0,802 & 60,348 & 45 & 0,501 & 91,571 \\
\hline 18 & 0,786 & 61,751 & 46 & 0,485 & 92,437 \\
\hline 19 & 0,774 & 63,133 & 47 & 0,477 & 93,289 \\
\hline 20 & 0,766 & 64,501 & 48 & 0,470 & 94,129 \\
\hline 21 & 0,749 & 65,837 & 49 & 0,452 & 94,936 \\
\hline 22 & 0,730 & 67,141 & 50 & 0,439 & 95,719 \\
\hline 23 & 0,711 & 68,411 & 51 & 0,436 & 96,498 \\
\hline 24 & 0,705 & 69,669 & 52 & 0,412 & 97,235 \\
\hline 25 & 0,692 & 70,905 & 53 & 0,410 & 97,967 \\
\hline 26 & 0,684 & 72,126 & 54 & 0,402 & 98,685 \\
\hline 27 & 0,664 & 73,312 & 55 & 0,382 & 99,367 \\
\hline \multirow[t]{2}{*}{28} & 0,643 & 74,460 & 56 & 0,354 & 100,000 \\
\hline & & & & Trace $=56$ & \\
\hline
\end{tabular}


TABLE 4

\section{Rotated Factor Matrix}

\begin{tabular}{|c|c|c|c|c|c|c|c|c|}
\hline Question Factor & 1 & 2 & 3 & 4 & 5 & 6 & 7 & 8 \\
\hline Q57 & 0,769 & & & & & & & \\
\hline Q73 & 0,644 & & & & & & & \\
\hline Q34 & 0,597 & & & & & & & \\
\hline Q25 & 0,573 & & & & & & & \\
\hline Q55 & 0,573 & & & & & & & \\
\hline Q46 & 0,548 & & & & & & & \\
\hline Q42 & 0,544 & & 0,304 & & & & & \\
\hline Q24 & 0,515 & & & & & & & \\
\hline Q23 & 0,481 & & & & 0,320 & & & \\
\hline Q64 & 0,462 & 0,325 & & & & & & \\
\hline Q63 & 0,429 & 0,396 & & & & & & \\
\hline Q33 & 0,428 & & & & & & & \\
\hline Q67 & 0,399 & 0,345 & & & & & & \\
\hline Q39 & 0,388 & & & & & & & \\
\hline Q59 & 0,388 & & & & & & & \\
\hline Q51 & 0,354 & & & & & & & \\
\hline Q43 & 0,349 & & & & & & & \\
\hline Q11 & 0,333 & & & & & & & \\
\hline Q68 & 0,327 & & & & & & & \\
\hline Q28 & 0,325 & & & & & & & \\
\hline Q66 & & 0,515 & & & & & & \\
\hline Q70 & & 0,482 & & & & & & \\
\hline Q49 & & 0,431 & 0,328 & & & & & \\
\hline Q62 & 0,401 & 0,431 & & & & & & \\
\hline Q45 & & 0,430 & & & & & & \\
\hline Q65 & 0,392 & 0,412 & & & & & & \\
\hline Q36 & & 0,396 & & & & & & \\
\hline Q54 & & 0,371 & & & & & & 0,321 \\
\hline Q60 & & 0,366 & & & & & & \\
\hline Q71 & & 0,310 & & & & & & \\
\hline Q52 & & 0,307 & & & & & & \\
\hline Q44 & & 0,226 & & & & & & \\
\hline Q31 & & & 0,533 & & & & & \\
\hline Q6 & & & 0,480 & & & & & \\
\hline Q5 & & & 0,423 & & & & & \\
\hline
\end{tabular}

\begin{tabular}{|c|c|c|c|c|}
\hline Q30 & & 0,403 & & \\
\hline Q4 & & 0,356 & & \\
\hline Q41 & & 0,323 & 0,330 & \\
\hline Q29 & & 0,292 & & \\
\hline Q14 & & & 0,675 & \\
\hline Q13 & 0,315 & & 0,630 & \\
\hline Q12 & & & 0,573 & \\
\hline Q15 & & & 0,303 & \\
\hline Q19 & & & & 0,438 \\
\hline Q21 & & & & 0,359 \\
\hline Q20 & & & & 0,359 \\
\hline Q27 & & & & 0,302 \\
\hline
\end{tabular}

Q7

Q2

Q8

Q3

Q10

Q72

Q47

Q26

Q37

Extraction Method: Principal Axis Factoring. Rotation Method: Varimax with Kaiser Normalisation. Rotation converged in 23 iterations.

TABLE 6

Matrix of Inter-Correlations of Sub-Scores

\begin{tabular}{lllllllll}
\hline & SS 1 & SS 2 & SS 3 & SS 4 & SS 5 & SS 6 & SS 7 & SS 8 \\
\hline SS 1 & 1,000 & 0,628 & 0,682 & 0,556 & 0,612 & 0,417 & 0,353 & 0,319 \\
SS 2 & 0,628 & 1,000 & 0,615 & 0,414 & 0,603 & 0,457 & 0,214 & 0,311 \\
SS 3 & 0,682 & 0,615 & 1,000 & 0,433 & 0,555 & 0,517 & 0,246 & 0,255 \\
SS 4 & 0,556 & 0,414 & 0,433 & 1,000 & 0,504 & 0,294 & 0,109 & 0,195 \\
SS 5 & 0,612 & 0,603 & 0,555 & 0,504 & 1,000 & 0,411 & 0,141 & 0,273 \\
SS 6 & 0,417 & 0,457 & 0,517 & 0,294 & 0,411 & 1,000 & 0,136 & 0,246 \\
SS 7 & 0,353 & 0,214 & 0,246 & 0,109 & 0,141 & 0,136 & 1,000 & 0,145 \\
SS 8 & 0,319 & 0,311 & 0,255 & 0,195 & 0,273 & 0,246 & 0,145 & 1,000
\end{tabular}

* All Correlations are significant at the 0,010 level (2-tailed).

$\mathrm{N}=4066$

TABLe 5

Distribution Statistics for the 8 Sub Scores

\begin{tabular}{|c|c|c|c|c|c|c|c|c|}
\hline Sub-scores & Mean & Median & Mode & Std. Deviation & Skewness & Std. Error & $\begin{array}{c}\text { Kurtosis } \\
\text { of Skewness }\end{array}$ & $\begin{array}{l}\text { Std. Error } \\
\text { of Kurtosis }\end{array}$ \\
\hline SS 1 & 3,172 & 3,238 & 3,52 & 0,765 & $-0,344$ & 0,038 & $-0,322$ & 0,077 \\
\hline SS 2 & 3,446 & 3,556 & 3,56 & 0,668 & $-0,317$ & 0,038 & $-0,038$ & 0,077 \\
\hline SS 3 & 3,060 & 3,167 & 3,33 & 0,855 & $-0,229$ & 0,038 & $-0,516$ & 0,077 \\
\hline SS 4 & 3,381 & 3,667 & 4,00 & 1,063 & $-0,398$ & 0,038 & $-0,766$ & 0,077 \\
\hline SS 5 & 3,369 & 3,333 & 3,33 & 0,770 & $-0,269$ & 0,038 & $-0,193$ & 0,077 \\
\hline SS 6 & 3,892 & 4,000 & 4,00 & 0,653 & $-0,768$ & 0,038 & 0,863 & 0,077 \\
\hline SS 7 & 3,026 & 3,000 & 3,00 & 1,010 & $-0,156$ & 0,038 & $-0,708$ & 0,077 \\
\hline SS 8 & 3,592 & 4,000 & 4,00 & 0,876 & $-0,605$ & 0,038 & $-0,030$ & 0,077 \\
\hline
\end{tabular}

$\mathrm{N}=4066$

Missing values $=0$

Minimum value $=1$

Maximum value $=5$ 
TABLE 7

EIgENVALUES OF THE UNREDUCED INTER-CORRELATION MATRIX OF SUB-SCORES

\begin{tabular}{lcccccc}
\hline & Initial Eigenvalues & \multicolumn{4}{c}{ Extraction Sums of Squared Loadings } \\
\hline Root & Total & $\begin{array}{c}\text { \% of } \\
\text { Variance }\end{array}$ & Cumulative & Total & \% of & Cumulative \\
\hline $\mathbf{1}$ & 3,827 & 47,841 & 47,841 & 3,361 & 42,018 & 42,018 \\
2 & 0,942 & 11,775 & 59,616 & & & \\
3 & 0,844 & 10,556 & 70,172 & & & \\
4 & 0,703 & 8,790 & 78,962 & & & \\
5 & 0,610 & 7,629 & 86,591 & & & \\
6 & 0,504 & 6,304 & 92,895 & & & \\
7 & 0,321 & 4,006 & 96,901 & & \\
8 & 0,248 & 3,099 & 100,000 & & \\
\hline
\end{tabular}

Trace $=8$

TABLE 8

Sorted ANd Rotated Factor MATrix of Sub-Scores

\begin{tabular}{lcc}
\hline Sub-scale & Scale $\mathbf{1}$ & $\mathbf{h} \mathbf{j}$ \\
\hline SS 1 & 0,858 & 0,660 \\
SS 2 & 0,823 & 0,591 \\
SS 3 & 0,811 & 0,595 \\
SS 4 & 0,616 & 0,372 \\
SS 5 & 0,601 & 0,330 \\
SS 6 & 0,564 & 0,316 \\
SS 8 & 0,374 & 0,131 \\
SS 7 & 0,304 & 0,129
\end{tabular}

Extraction Method: Principal Axis Factoring. 1 factor extracted. 5 iterations required.

The intercorrelations of the subscores are depicted in Table 6 . From Table 6 it is clear that all the intercorrelations are significant at the 0,01 significance level.

Second Level Factor Analysis

Sub-scores were calculated on the eight obtained factors. The Kaiser-Meyer-Olkin Measure of sampling adequacy $(0,875)$ and the Bartlett's Test of sphericity (Chi square $=11979,791 ; \mathrm{df}=28 ; \mathrm{p}=$ 0,000 ) were conducted on the inter-correlation matrix of the eight sub-scores. It is clear that this matrix, comprising of the eight subscores, also complies with the requirements for factor analysis.

The eigenvalues were calculated on the unreduced intercorrelation matrix of the subscores. The eigenvalues of the unreduced inter-correlation matrix of subscores appear in Table 7. It is clear from Table 7 that one factor was postulated.

In Table 8 , the respective loadings of the sub-scores on the one factor extracted are presented.

\section{Reliability}

The internal consistency of the single scale obtained from factor analyses (the degree of homogeneity among the items) was computed using Cronbach Coefficient Alpha. Table 9 provides the item reliability statistics for the scale. The closer the value of the Cronbach Coefficient Alpha to 1 the greater the reliability of the scale. Hence, the Cronbach Coefficient Alpha of 0,945 indicates that the scale is highly reliable and can consistently measure the dimensions of the magnitude of organisational culture it is designed to measure. In other words, the measuring instrument is capable of consistently reflecting the same underlying constructs. Furthermore, it indicates a high degree of homogeneity amongst the scale items.
TABLE 9

ITEM STATISTICS OF THE CAI

\begin{tabular}{|c|c|c|c|c|}
\hline & $\begin{array}{l}\text { Scale Mean } \\
\text { If Item } \\
\text { Deleted }\end{array}$ & $\begin{array}{l}\text { Scale Variance } \\
\text { If Item } \\
\text { Deleted }\end{array}$ & $\begin{array}{l}\text { Corrected } \\
\text { Item-Total- } \\
\text { Correlation }\end{array}$ & $\begin{array}{l}\text { Alpha } \\
\text { if Item } \\
\text { Deleted }\end{array}$ \\
\hline Q2 & 182,310 & 1120,033 & 0,300 & 0,945 \\
\hline Q3 & 182,416 & 1113,948 & 0,327 & 0,945 \\
\hline Q4 & 182,917 & 1094,479 & 0,526 & 0,944 \\
\hline Q5 & 183,421 & 1102,019 & 0,441 & 0,944 \\
\hline Q6 & 183,172 & 1093,445 & 0,473 & 0,944 \\
\hline Q7 & 182,126 & 1125,377 & 0,194 & 0,945 \\
\hline Q8 & 182,333 & 1109,236 & 0,396 & 0,944 \\
\hline Q10 & 182,539 & 1104,559 & 0,474 & 0,944 \\
\hline Q11 & 182,775 & 1100,582 & 0,560 & 0,944 \\
\hline Q12 & 182,822 & 1094,317 & 0,513 & 0,944 \\
\hline Q13 & 182,912 & 1095,447 & 0,460 & 0,944 \\
\hline Q14 & 182,835 & 1095,843 & 0,506 & 0,944 \\
\hline Q15 & 182,434 & 1106,652 & 0,381 & 0,944 \\
\hline Q19 & 183,246 & 1097,836 & 0,443 & 0,944 \\
\hline Q20 & 182,797 & 1104,650 & 0,366 & 0,945 \\
\hline Q21 & 182,518 & 1110,650 & 0,324 & 0,945 \\
\hline Q23 & 183,352 & 1083,842 & 0,584 & 0,943 \\
\hline Q24 & 183,410 & 1089,231 & 0,612 & 0,943 \\
\hline Q25 & 183,228 & 1086,502 & 0,560 & 0,943 \\
\hline Q26 & 182,655 & 1117,183 & 0,242 & 0,945 \\
\hline Q27 & 182,657 & 1112,705 & 0,361 & 0,944 \\
\hline Q28 & 183,209 & 1086,742 & 0,573 & 0,943 \\
\hline Q29 & 182,781 & 1096,212 & 0,520 & 0,944 \\
\hline Q30 & 182,934 & 1091,020 & 0,586 & 0,943 \\
\hline Q31 & 183,243 & 1091,040 & 0,561 & 0,943 \\
\hline Q33 & 183,098 & 1092,359 & 0,580 & 0,943 \\
\hline Q34 & 183,024 & 1082,393 & 0,667 & 0,943 \\
\hline Q36 & 182,333 & 1122,885 & 0,203 & 0,945 \\
\hline Q37 & 182,636 & 1116,514 & 0,304 & 0,945 \\
\hline Q39 & 183,280 & 1089,542 & 0,536 & 0,944 \\
\hline Q41 & 183,374 & 1093,897 & 0,529 & 0,944 \\
\hline Q42 & 183,493 & 1084,821 & 0,602 & 0,943 \\
\hline Q43 & 183,256 & 1093,593 & 0,529 & 0,944 \\
\hline Q44 & 182,838 & 1104,725 & 0,415 & 0,944 \\
\hline Q45 & 182,919 & 1103,466 & 0,453 & 0,944 \\
\hline Q46 & 183,076 & 1090,547 & 0,569 & 0,943 \\
\hline Q47 & 183,350 & 1103,241 & 0,405 & 0,944 \\
\hline Q49 & 182,981 & 1092,726 & 0,578 & 0,943 \\
\hline Q51 & 183,080 & 1104,398 & 0,427 & 0,944 \\
\hline Q52 & 182,617 & 1106,825 & 0,444 & 0,944 \\
\hline Q54 & 182,556 & 1116,923 & 0,310 & 0,945 \\
\hline Q55 & 182,939 & 1084,958 & 0,621 & 0,943 \\
\hline Q57 & 182,958 & 1092,115 & 0,470 & 0,944 \\
\hline Q59 & 183,427 & 1097,552 & 0,465 & 0,944 \\
\hline Q60 & 183,652 & 1097,560 & 0,480 & 0,944 \\
\hline Q62 & 182,614 & 1096,302 & 0,567 & 0,943 \\
\hline Q63 & 182,702 & 1095,184 & 0,577 & 0,943 \\
\hline Q64 & 182,889 & 1089,848 & 0,596 & 0,943 \\
\hline Q65 & 182,856 & 1093,133 & 0,586 & 0,943 \\
\hline Q66 & 182,451 & 1098,969 & 0,499 & 0,944 \\
\hline Q67 & 182,801 & 1096,741 & 0,547 & 0,944 \\
\hline Q68 & 183,284 & 1106,092 & 0,406 & 0,944 \\
\hline Q70 & 182,767 & 1098,537 & 0,507 & 0,944 \\
\hline Q71 & 182,827 & 1102,382 & 0,471 & 0,944 \\
\hline Q73 & 182,823 & 1088,629 & 0,603 & 0,943 \\
\hline Q72 & 183,072 & 1128,213 & 0,095 & 0,946 \\
\hline
\end{tabular}

$\mathrm{N}$ of Cases $=4066$

$\mathrm{N}$ of Items $=56$ Cronbach Coefficient Alpha $=0,945$ 
Thus far the data set has been reduced to a single scale and it has been established that the scale is highly reliable. The six theoretical dimensions of the CAI could not be replicated by factor analysis. The next phase of the statistical process comprises analysis of variance. The results thereof are reported in the next section.

Phase 1l: Inferential Statistical Analyses for testing differences between groups

In this section the results of the inferential statistical analyses followed by the Cramer's V tests are presented for the four different groups i.e. race, gender, age and language.

In cases where, the ANOVA (for more than two groups) or the ttest (for two groups) does not show any significant differences in culture mean scores based on race, gender, age or language group, will possibly indicate that the Culture Assessment Instrument (CAI) is not biased.

Further statistical analyses on an item level are conducted to identify those items that could effectively distinguish culture differences between the different race, gender, age and language groups in order to scrutinize those items for possible bias and unfairness in their particular wordings. The statistical procedure conducted for this purpose, is the Cramer's V test, a measure of association. The Cramer's $\mathrm{V}$ test will be used to test the hypothesis on bias or fairness on an item level. In respect of Cramer's V, a Chi square coefficient of $>0,2$ was set. Thus all items with chi square values equal to or larger than 0,2 will indicate prominent differences between groups.

Hypothesis 1: There are significant differences in the culture mean scores of the different race groups

The first hypothesis tested for bias or unfairness on the race group level. Table 10 shows the culture mean scores for the different racial categories.

TABLE 10

Culture Mean Scores for Different Categories of Race

\begin{tabular}{lccc}
\hline Race & Mean & Std. Deviation & N \\
\hline 1 White & 3,503 & 0,563 & 1073 \\
2 Black & 3,399 & 0,591 & 292 \\
3 Coloured & 3,189 & 0,731 & 125 \\
4 Indian & 3,047 & 0,641 & 908 \\
\hline Total & 3,295 & 0,643 & 2396 \\
\hline
\end{tabular}

It should be noted that the group means are different and that the group sizes vary, therefore the Levene's test for equality of error variances should be conducted. The Levene's test shows that the error variances of groups are significantly different. The Dunnett post hoc test should therefore be interpreted.

From Table 11 it can be inferred that there are significant culture differences between racial groups. The partial eta squared indicates that $11,2 \%$ of the variance in culture mean scores can be attributed to culture differences.

Table 12, depicts the outcome of the Dunnett post hoc test, which also shows significant differences between the different race categories (marked with an *).

The following discussion will focus on the measure of association (Cramer's V) which is a statistical tool used to identify those items that could effectively distinguish culture differences between the different race groups. A value of $>0,2$ was set, thus all items with values equal to or larger than 0,2 will be considered to show a moderate association.
TABLE 11

ANOVA: Testing for Culture Differences BetWeen Race Groups

\begin{tabular}{|c|c|c|c|c|c|c|}
\hline Source & $\begin{array}{l}\text { Type III sum } \\
\text { of squares }\end{array}$ & Df & $\begin{array}{l}\text { Mean } \\
\text { square }\end{array}$ & F & P(f) Sig. & $\begin{array}{c}\text { Partial eta } \\
\text { squared }\end{array}$ \\
\hline Corrected model & 111,093 & 3 & 37,031 & 100,748 & 0,000 & 0,112 \\
\hline Intercept & 12614,307 & 1 & 12614,3 & 34318,9 & 0,000 & 0,935 \\
\hline RACE & 111,093 & 3 & 37,031 & 100,748 & 0,000 & 0,112 \\
\hline Error & 879,9424 & 2394 & 0,368 & & & \\
\hline Total & 7036,778 & 2398 & & & & \\
\hline Corrected total & 891,035 & 2397 & & & & \\
\hline
\end{tabular}

R Squared $=0,112$ (adjusted R squared $=0,111$ )

Only item 25 - "Employment takes place without discrimination in terms of race, gender, age and language", detected a significant difference between racial groups. It seems that the wording of the item is not biased or stereotyping any particular group.

Hypothesis 2: There are significant differences in the culture mean scores of the different gender groups

The second hypothesis tested for bias or unfairness on gender group level. Table 13 provides the culture mean scores of gender groups.

Table 13 shows that there are more males $(52 \%)$ than females $(48 \%)$ and the results of the Levene's test of equality of error variances show that the error variances are significantly different and the results of t-tests for unequal variances should therefore be interpreted.

Table 14, depicts the results of the t-test and shows Partial eta squared of $0,03 \%$ which suggests that only an insignificant small proportion of the variance can be attributed to culture difference scores.

The following discussion will focus on the results of the Cramer's V test, to identify those items under this category that could effectively distinguish culture differences between the different gender categories. A Chi square value of $>0,2$ was set, thus all items with values equal to or larger than 0,2 will be scrutinized for possible bias or unfairness.

Only item number 72, "Managers in this division have the necessary leadership skills", show that the Chi square value is greater than 0,2 , indicating a prominent difference of gender group response. On closer scrutiny, the item does not show any bias or unfairness to any particular gender group because the item is worded in such a way that it conveys the same meaning, i.e. conceptual and semantic equivalence, irrespective of gender. Both male and female responses are based on their perception, not influenced by their particular gender.

Hypothesis 3: There are significant differences in the culture mean scores of the different age groups

The third hypothesis tested for bias or unfairness on age group levels. Table 15 illustrates the culture mean scores for different age groups.

Table 15 depicts that the age group 24 years and less are in the majority and ages 46 years and older are in the minority. The Levene's test of equality of error variances detected significant differences in error variances. The Dunnett post hoc tests should therefore be interpreted. Table 16 will show the outcome of the analysis of variance. 
TABLE 12

Dunnett Post Hoc Comparison Tests for Race Groups

\begin{tabular}{|c|c|c|c|c|c|c|c|}
\hline & \multirow[b]{2}{*}{ (I) Race } & \multirow[b]{2}{*}{ (J) Race } & \multirow[b]{2}{*}{ Mean difference (I-J) } & \multirow[b]{2}{*}{ Std. Error } & \multirow[b]{2}{*}{ Sig } & \multicolumn{2}{|c|}{$95 \%$ confidence interval } \\
\hline & & & & & & Lower bound & Lower bound \\
\hline \multirow[t]{14}{*}{ Dunnet T3 } & 1 & 1 & & & & & \\
\hline & & $2+$ & 0,1035 & 0,0385 & 0,045 & 0,0015 & 0,2054 \\
\hline & & $3+$ & 0,4230 & 0,0676 & 0,000 & 0,2427 & 0,6034 \\
\hline & & $4^{+}$ & 0,4557 & 0,0273 & 0,000 & 0,3837 & 0,5277 \\
\hline & 2 & $\begin{array}{c}1+ \\
2\end{array}$ & 0,1035 & 0,0385 & 0,045 & $-0,2054$ & $-0,0015$ \\
\hline & & $3+$ & 0,3195 & 0,0739 & 0,000 & 0,1230 & 0,5161 \\
\hline & & $4+$ & 0,3522 & 0,0405 & 0,000 & 0,2451 & 0,4593 \\
\hline & 3 & $1+$ & 0,4230 & 0,0676 & 0,000 & $-0,6034$ & $-0,2427$ \\
\hline & & $2+$ & 0,3195 & 0,0739 & 0,000 & $-0,5161$ & $-0,1230$ \\
\hline & & 3 & & & & & \\
\hline & & 4 & 0,0327 & 0,0687 & 0,998 & 0,1506 & 0,2159 \\
\hline & 4 & $1+$ & 0,4557 & 0,0273 & 0,000 & $-0,5277$ & $-0,3837$ \\
\hline & & $2+$ & 0,3522 & 0,0405 & 0,000 & $-0,4593$ & $-0,2451$ \\
\hline & & 3 & 0,0327 & 0,0687 & 0,998 & $-0,2159$ & 0,1506 \\
\hline
\end{tabular}

$1=$ white; 2 = black; 3 = coloured; 4 = Indian/Asian

The mean difference is significant at the 0,05 level.

TABLE 13

Culture Mean Scores for Different Gender Groups

\begin{tabular}{lccc}
\hline Gender & Mean & Std. Deviation & N \\
\hline Male & 3,3611 & 0,60899 & 2022 \\
Female & 3,2933 & 0,57576 & 1869 \\
Total & 3,3286 & 0,59415 & 3891
\end{tabular}

TABLE 14

T-Test for Culture Differences of Gender Groups

\begin{tabular}{lcccccc}
\hline & $\mathbf{t}$ & $\mathrm{df}$ & $\begin{array}{c}\mathbf{P}(\mathrm{t}) \\
\text { differ }\end{array}$ & $\begin{array}{c}\text { Mean } \\
\text { squared }\end{array}$ & SE & $\begin{array}{c}\text { Partial } \\
\text { eta }\end{array}$ \\
\hline Equal & 3,559 & 3889 & 0,000 & 0,0677 & 0,01904 & 0,003 \\
Variances & & & & & & \\
Assumed & & & & & & \\
Equal & 3,566 & 3887,015 & 0,000 & 0,0677 & 0,01899 & 0,003 \\
Variances & & & & & & \\
Not & & & & & & \\
Assumed & & & & & & \\
\hline
\end{tabular}

TABLE 15

Culture Mean Scores for Different Age Groups

\begin{tabular}{lccc}
\hline Age & Mean & Std. Deviation & N \\
\hline 24 and younger & 3,4291 & 0,53630 & 4352 \\
$25-35$ & 3,2811 & 0,59105 & 1799 \\
$36-45$ & 3,3433 & 0,60297 & 1001 \\
46 and older & 3,3771 & 0,61086 & 636 \\
Total & 3,3296 & 0,59360 & 3871 \\
\hline
\end{tabular}

TABLE 16

ANOVA-Test for Age Group Differences

\begin{tabular}{lcccccc}
\hline Source & $\begin{array}{c}\text { Type III sum } \\
\text { of squares }\end{array}$ & Df & $\begin{array}{c}\text { Mean } \\
\text { square }\end{array}$ & F & P(f) Sig. Partial eta \\
squared
\end{tabular}

R Squared $=0,007$ (adjusted R squared $=0,007$ ) 
TABLE 17

Dunnett Post Hoc Comparison Test for Age Groups

\begin{tabular}{|c|c|c|c|c|c|c|c|}
\hline & \multirow[b]{2}{*}{ (I) Age } & \multirow[b]{2}{*}{ (J) Age } & \multirow[b]{2}{*}{ Mean difference (I-J) } & \multirow[b]{2}{*}{ Std. Error } & \multirow[b]{2}{*}{ Sig } & \multicolumn{2}{|c|}{$95 \%$ confidence interval } \\
\hline & & & & & & Lower bound & Lower bound \\
\hline \multirow[t]{12}{*}{ Dunnet T3 } & 24 and younger & $25-35$ & 0,1479 * & 0,02925 & 0,000 & 0,0708 & 0,2251 \\
\hline & & $36-45$ & $0,0857^{*}$ & 0,03201 & 0,044 & 0,0014 & 0,1701 \\
\hline & & 46 and more & 0,0520 & 0,03533 & 0,599 & $-0,0411$ & 0,1451 \\
\hline & $25-35$ & 24 and less & $-0,1479 *$ & 0,02925 & 0,000 & $-0,2251$ & $-0,0708$ \\
\hline & & $25-35$ & $-0,0622$ & 0,02361 & 0,050 & $-0,1243$ & 0,0000 \\
\hline & & $36-45$ & $-0,0959 *$ & 0,02794 & 0,004 & $-0,1696$ & $-0,0223$ \\
\hline & $36-45$ & 24 and less & $-0,0857^{*}$ & 0,03201 & 0,044 & $-0,1701$ & $-0,0014$ \\
\hline & & $25-35$ & 0,0622 & 0,02361 & 0,050 & 0,0000 & 0,1243 \\
\hline & & $36-45$ & $-0,0338$ & 0,03082 & 0,853 & $-0,1150$ & 0,0474 \\
\hline & 46 and more & 24 and less & $-0,0520$ & 0,03533 & 0,599 & $-0,1451$ & 0,0411 \\
\hline & & $25-35$ & $0,0959 *$ & 0,02794 & 0,004 & 0,0223 & 0,1696 \\
\hline & & $36-45$ & 0,0338 & 0,03082 & 0,853 & $-0,0474$ & 0,1150 \\
\hline
\end{tabular}

Based on observed means

*The mean difference is significant at 0,05 level

Table 16 depicts the ANOVA test which shows Partial eta squared of $0,7 \%$ suggesting that an insignificant small proportion of variance could be attributed to culture differences.

Table 17 depicts the outcome of the Dunnett post hoc tests, where asterisks indicate all those age groups with significant differences, i.e. the age group which is 24 yrs and younger is significantly different to $25-35$ yrs and $36-45$ yrs age groups.

The following section deals with the results of the measure of association.

There is no item that is equal to or larger than the set criteria of 0,2 . It can be inferred that there is no item significantly related to age group differences.

Hypothesis 4: There are significant differences in the culture mean scores of the different language groups

The fourth hypothesis tested for bias or unfairness on a language group level.

TABLE 18

Culture Mean Scores for Different Language Groups

\begin{tabular}{lccc}
\hline Language & Mean & Std. Deviation & N \\
\hline Afrikaans & 3,4235 & 0,47485 & 1014 \\
English + other & 3,1937 & 0,52850 & 246 \\
\hline Total & 3,3786 & 0,49405 & 1260 \\
\hline
\end{tabular}

Table 18 depicts the results of the culture mean scores for different language categories. Afrikaans has majority $(80,5 \%)$ of participants as compared to English and other language group $(19,5 \%)$ and a Levene's test for equality of error variances should therefore be conducted. The Levene's test yielded significantly different error variances for language groups. The t-test for unequal variances should therefore be interpreted.
Table 19 depicts the outcome of the t-test and shows a Partial eta squared of $3,4 \%$ indicating that only a small portion of the variance can be attributed to culture differences.

The following section will focus on the results of the Cramer's V test in order to establish whether significant differences for the two language groups occur on an item level.

TABLE 19

T-Tests for Language Group Differences

\begin{tabular}{lcccccc}
\hline & $\mathbf{t}$ & Df & $\mathbf{P}(\mathrm{t})$ & $\begin{array}{c}\text { Mean } \\
\text { Differ }\end{array}$ & $\begin{array}{c}\text { SE } \\
\text { Differ }\end{array}$ & $\begin{array}{c}\text { Partial } \\
\text { eta } \\
\text { squared }\end{array}$ \\
\hline $\begin{array}{l}\text { Equal } \\
\text { Variances }\end{array}$ & 6,658 & 1258 & 0,000 & 0,2298 & 0,03452 & 0,034 \\
Assumed & & & & & & \\
\hline Equal & 6,238 & 347,142 & 0,000 & 0,2298 & 0,03685 & 0,034 \\
$\begin{array}{l}\text { Variances not } \\
\text { Assumed }\end{array}$ & & & & & & \\
\hline
\end{tabular}

Table 20 depicts items $2,6,7,8,10,11,30,33,34,64 \& 73$, as above or equal to the set Chi square value of 0,2 . Each item was individually analysed and the following conclusion was reached:

- The items were worded or constructed in such a way that it does not offend or stereotype any of the language group under study.

- The items were worded in such a way that it conveys the same meaning for the different language groups, i.e. semantic equivalence.

- The criterion of conceptual and semantic equivalence is also met in the construction of these items.

- The different language groups had the same understanding in such a way that the response provided is not influenced by language affiliation but by the respondent perception.

- The items were worded in such a way that the respondents' response was based on their perception not on their language affiliation. 
TABLE 20

Cramer's V Test for Language Group

DIFFERENCES ON ITEM LEVEL

(ITEMS IN BOLD SHOW PROMINENT LANGUAGE GROUP DIFFERENCES)

\section{No. Item}

2. I understand the overall objectives of the organisation.

3. I am in possession of measurable standards of the results to be achieved.

4. Subordinates are given the opportunity to make contributions with regard to goals and standards that are determined for them.

5. Written objective contracts for at least the next 12 months are given to employees.

6. Feedback sessions are held with employees three times a year about the manner in which outputs are obtained, in order to evaluate their performance.

7. I know precisely who our target market and clients are.

8. We really spare no efforts in understanding 0,230 the needs of our customers.

0,000

10. We listen actively in order to understand the 0,220 current and future needs of our customers.

11. The company continuously lives according 0,229 to its core values.

12. Our employees display a professional image 0,090 in their contact with the public, their elationship with colleagues and their general behaviour at work.

13. Employees respect the property and other possessions of the organisation. They protect it and do not take anything belonging to the organisation.

14. Employees display an attitude of doing things 0,039 right the first time.

15. We provide our products/services totally free from any discrimination (race or gender).

19. We are satisfied with the technological equipment (systems and computers) as resources to do our work.

20. The physical appearance of the workplace (buildings, furniture and reception areas) supports the company's image.

21. The way we dress supports the organisation's image.

23. In the company employment equity has become a reality for all employees.

24. The company knows what employees' needs are

25. Employment takes place without discrimination 0,111 in terms of gender, race or language.

26. In order to adjust to the rapidly changing political situation in South Africa it is desirable to appoint people of colour at all levels of authority in our organisation.

27. The company is a sought after employer in the 0,12 employment market.

28. We retain our best workers.

29. Internal training is of high standing quality.

30. Managers and supervisors are sufficiently prepared for their task through training.

31. Performance evaluation is succeeded with
33. The company responds quickly to changes rate adjustments)

34. The company is managed effectively on all 0,238 levels.

36. The minimum duplication of work occurs. 0,075

0,000

0,135

37. I know exactly what my role in my work 0,130 0,000

39. A visible trust relationship exists between 0,093 employees and management.

41. I am adequately informed about the work 0,183 activities of other divisions in the company.

42. There are sufficient personal discussions ("eyeball sessions") between managers and their employees.

43. Higher level management takes purposeful actions to make contact with employees on lower levels.

44. I have an open channel of communication to 0,170 my immediate supervisor/manager.

45. Purposeful action is taken to involve all $\quad 0,043$ employees in decision making.

46. My work environment could be described as 0,016 participative.

47. When management make decisions that affect 0,167 employees, the persons involved are consulted.

49. Employees and immediate supervisors/managers 0,174 collectively formulate objectives.

51. My work results can be determined accurately. 0,059

52. Control of own work is promoted.

Persons in positions of power delegate
sufficiently to complete work successfully.

55. I believe that my own personal objectives can 0,090 be satisfied in the company.

57. I don't mind doing extra work if necessary $\quad 0,035$ ("going the extra mile").

0,000

0,019

0,001

0,000

0,675

0,988

0,000

0,000

0,364

0,000

0,336

0,038

0,822

0,001 to actual results.

60. The company's remuneration system is fair. $\quad 0,170$

0,000

62. The organisation is known for its innovative 0,135 services.

63. Employees are continuously encouraged to 0,130 develop better work procedures and methods.

64. Rules and regulations are continuously $\quad 0,210$ reviewed to cope with change.

65. In our organisation employees are self- $\quad 0,098$ motivated and have the ability to control their own work.

66. Management believes employees are self- $\quad 0,085$ motivated and have the ability to control their own work.

67. There is good teamwork in my department. $\quad 0,070$

68. The work proceedings at the different divisions 0,170 of the company are being co-ordinated.

70. We solve our differences. We get down to the 0,122 root of our differences.

71. Conflict is resolved by confronting those 0,039 involved with the problem and mutually working towards solutions.

72. Managers in this division have the necessary 0,160 leadership skills.

73. I believe that our management has the vision 0,233 and knowledge to lead the organisation successfully into the future. 


\section{DISCUSSION}

Findings Regarding the Empirical Research Objectives The primary objective of the empirical research was to determine the ability of the CAI to validly and reliably, without bias or unfairness, distinguish between the mean culture scores of the different race, gender, age and language groups, in other words to determine the bias or fairness of the CAI.

For the purpose of this study, the following four hypotheses were tested:

- H1: There are significant differences in the mean scores of the different race groups the CAI of Martins (1989).

- H2: There are significant differences in the mean scores of the different gender groups on the CAI of Martins (1989).

- H3: There are significant differences in the mean scores of the different age groups on the CAI of Martins (1989).

- H4: There are significant differences in the mean scores of the different language groups on the CAI of Martins (1989).

The empirical finding for the first hypothesis is that there are significant differences between racial groups. The partial eta squared indicated that $11,2 \%$ of the variance could be attributed to differences in culture mean scores.

Significant differences between racial groups on an item level were also detected, which could be an indication of item bias. It seemed however that the wording of the items was not stereotyping any particular group.

The empirical finding for the second and third hypotheses, i.e. gender and age, respectively, did not meet the expectation that the instrument would identify significant differences in the mean culture scores of the different gender and age groups.

The empirical finding on the fourth hypothesis showed that there were significant differences on the mean scores of the different language groups, but according to the t-test the outcome of the language group differences shows a partial eta squared of $3,4 \%$ indicating that only a small portion of the variance can be attributed to culture differences. Significant differences between racial groups on an item level were also detected, which could be an indication of item bias. It seemed however that the wording of the items was not stereotyping any particular group.

Based on the literature review, however, a priori differences in the cultures between different race and language groups were postulated. There were no significant differences between the different gender and age groups.

Possible limitations of the study are that only a limited number of organisations across different industries participated in the survey and that findings can not be generalised all South African companies. Also, only 56 items of the original 89-item instrument were used, limiting observations and findings only to these items.

\section{Conclusions}

The purpose of this study was to conduct an assessment of bias and fairness of Martins (1989) Culture Assessment Instrument (CAI), in the context of race, gender, age and language groups. Elenkov (1998) identified one of the biggest obstacles in crosscultural research as the transferability of these studies to other cultures. Individuals come from different cultural groups, which also affects their mindset and framework and they would therefore interpret stimuli in different ways. A questionnaire item is said to be biased or unfair, when the response of the participant is influenced by race, gender, age and language and not by the individual perception on the raised issue.

In this article, the results of the various statistical procedures were documented and main observations were made. The results of the descriptive statistics, factor analysis, inferential statistics and measure of association (Cramer's V) were portrayed.

The study aimed at determining whether different racial, gender, age and language groups display different response patterns with respect to test items in respect of, race, gender, age and language groups. Individual items were scrutinized for any form of bias or unfairness.

The results of item categorization exercises were reflected. Based on the Cramer's V statistics, only race and language showed significant differences on an item level. A closer scrutiny of these items revealed no bias or stereotyping in their wording.

Suggestions for further research

It is suggested that the CAI and the items it consists of, are scrutinized in terms of the generally accepted criteria for test and item construction. Several limitations in test and item construction have been identified. (See Du Toit, 2003; Petkoon, 2003; Smith, 2003 in this regard).

It is also suggested that deeper levels of culture are included in the instrument. A possible suggestion is also to focus the instrument on unique aspects of culture, such as myths, stories and rituals about heroes, founders and champions, rather than focusing on generic business processes of organisations.

\section{ACKNOWLEDGEMENT}

The authors are indebted to Prof Nico Martins of Organisational Diagnostics for providing the data set for conducting this research. The 56-item CAI used in this research was abstracted from a larger item pool collected across various organisations and does not constitute the original Organisational Culture Survey of Prof Martins. Data collected from each organisation by means of the survey were supplemented by qualitative methods.

The authors would like to thank Riëtte Eiselen and her staff from Statcon at RAU for their professional service and valuable contribution regarding the data analyses for this project.

\section{REFERENCES}

Amsa, P. (1986). Organisational culture and work group behaviour: an empirical study, Journal of Management Studies, 23 (3), May, 347-362.

Ashkanasy, N.M., Broadfoot, L.E. \& Falkus, S. (2000). Questionnaire Measures of Organisational Culture. In Ashkanasy, N.M., Wilderom, C.P.M. and Peterson, M.F. (Eds), Handbook of organisational culture and climate (31-145). Beverly Hills, CA: Sage Publications, Inc.

Barley, S.R., Meyer, G.W., \& Gash, D.C. (1988) Cultures of culture: Academics, practitioners and pragmatics of normative control. Administrative Science Quarterly, 33 ,2460.

Barnett, G.A. (1988). Communication and organisational culture, in Goldhaber, G.M. and Barnett, G.A. (Eds). The Handbook of Organisational Communication, Ablex, Norwood, 101-30.

Bookbinder, S.M. (1984). Measuring and managing corporate culture, Human Resource Planning, 7 (1), 47-53.

Cooke, R.A. \& Rousseau, D.M. (1988). Behavioural norms and expectations: a quantitative approach to the assessment of organisational culture, Group and Organisation Studies, 13, 245-273.

Deal, T.E. \& Kennedy, A.A. (1982). Corporate Culture, AddisonWesley, Reading, MA.

Denison, D.R. (1996). What is the difference between organisational culture and organisational climate? A native's point of view on a decade of paradigm wars. Academy of Management Review, 21 ,619-654 
Desatnick, R.L. (1986). Management climate surveys: a way to uncover an organisation's culture, Personnel, 63 (5), 49-54.

$\mathrm{Du}$ Toit, W.F. (2003). The discriminant validity of the culture assessment instrument: a Comparison of company cultures. Unpublished Doctoral thesis, Johannesburg Rand Afrikaans University.

Elenkov, D.S. (1998). Can American Management concepts work in Russia? A cross-cultural comparative study. California Management Review, 40 (4), 133-153.

Foxcroft, C. \& Roodt, G. (eds.) An introduction to psychological assessment in the South African context. Cape Town: Oxford University Press.

Frost, P.J., Moore, L., Louis, M., Lundberg, C. \& Martin. (Eds.) (1991). Reframing organisational culture. Beverly Hills, CA: Sage Publications.

Gabriel, Y. (1991). Turning facts into stories and stories into facts: a hermeneutic exploration of organisational folklore, Human Relations, 44 (8), 857-75.

Groeschl, S. \& Doherty, L. (2000). Conceptualising Culture. Cross Cultural Management - An International Journal, 7 (4), 12-17.

Hofstede, G. (1986). The usefulness of the 'organisational culture' concept, Journal of Management Studies, 23 (3), 253-57.

Hui, C.H., \& Triandis, H.C. (1989). Effects of culture and response format on extreme response styles. Journal of CrossCultural Psychology, 20, 296-309

Kanjee, A. (2002). Cross-cultural test adaptation and translation. In C. Foxcroft \& G. Roodt (eds.) An introduction to psychological assessment in the South African context. Cape Town: Oxford University Press.

Lewis, D. (1995). Researching strategic change - methodologies, methods and techniques. In Hussey, D. (Ed.), Rethinking Strategic Management, John Wiley and Sons, London, 269316.

Martin. \& Meyerson, D. (1988). Organisational culture and the denial, channelling and acknowledgement of ambiguity. In Pondy, L.R., Boland, jr. R.J. \& Thomas. (Eds.) Managing ambiguity and change. New York, NY: John Wiley \& sons.

Martin, J. (1992). Cultures in organisations: Three Perspectives. New York: Oxford University Press.

Martins, N. (1989). Organisasiekultuur in 'n finansiele instelling. Ongepubliseerde D.Phil-proefskrif. Pretoria: University of Pretoria.

Nossiter, V. \& Biberman, G. (1990). Projective drawings and metaphor:analysis of organisational culture. Journal of Managerial Psychology, 5 (3) 13-6

Osterlind, S.J. (1983). Test Item Bias: Quantitative Applications in the Social Sciences. Beverly Hills, CA: Sage Publications, Inc.

O'Reilly,C.A.,III, Chatman, J.A. \& Caldwell, D.F. (1991). People and organisational culture: A profile comparison approach to assessing person-organisational fit. Academy of Management Journal, 34, 487-516.

Ott, J.S. (1989). The organisational culture perspective. Pacific Grove,CA: Brooks/Cole.

Owen, K. (1989). Bias in test items: An exploration of item content and item format. Pretoria: Human Science Research Council.
Peters, T.J. \& Waterman, R.H. (1982). In Search of Excellence: Lessons from America's Best-Run Companies, New York: Harper $\&$ Row.

Petkoon, L.J. (2003). The discrimant validity of the culture assessment instrument: a comparison of company sub-cultures. Unpublished doctoral thesis, Johannesburg Rand Afrikaans University.

Reichers, A.E. \& Schneider, B. (1990). Climate and culture:An evolution of constructs. In B.Schneider (Ed), Organisational climate and culture (pp.5-39). San Francisco: Jossey-Bass.

Rentsch, J.R. (1990). Climate and culture:Interaction and qualitative differences in organisational meanings. Journal of Applied Psychology, 75, 668-681.

Reynierse, J.H. (1986). Measuring corporate culture, The Business Magazine, September-October, pp. 64-67.

Reynierse, J.H. \& Harker, J.B. (1986). Measuring and managing organisational culture, Human Resource Planning, 9 (1), 1-8.

Reynolds, P.D. (1986). Organisational culture as related to industry, position and performance: a preliminary report, Journal of Management Studies, 23, 333-345.

Rousseau, D.M. (1990) Assessing organisational culture: The case for multiple methods. In B. Schneider (Ed.) Organisational climate and culture (pp.153-192). San Francisco: Jossey-Bass.

Schein, E.H. (1990). Organisational culture. American Psychologist, 45, 109-119.

Schepers, J.M. (1992). Toetskonstruksie: Teorie en praktyk. Johannesburg: RAU Press.

Smircich, L. (1983). Concepts of culture and organisational analysis, Administrative Science Quarterly, 28 (83), 339-59.

Smith, S.A. (2003). An evaluation of response scale formats of the culture assessment instrument. Unpublished Doctoral Thesis, Johannesburg Rand Afrikaans University.

Triandis, H.C. (1994). Cross-Cultural industrial and organisational psychology. In H.C.Triandis, M.D. Dunnette, $\&$ L. Hough (Eds.), Handbook of industrial and organisational psychology (2nd ed., Vol.4, pp103-172). Palo Alto, CA: Consulting Psychologists Press.

Tucker, R.W., McCoy, W.J. \& Evans, L.C. (1990), Can questionnaires objectively assess organisational culture? Journal of Managerial Psychology, 5 (4), 4-11.

Van Maanen, J. (1991). The smile factory: Work at Disneyland. In Frost, P.J., Moore, L., Louis, M., Lundberg, C. \& Martin. (Eds). Reframing organisational culture. Beverly Hills, CA: Sage Publications.

Wiener, Y. (1988). Forms of value systems: a focus on organisational effectiveness and cultural change and maintenance, Academy of Management Review, 13 (4), 534545 .

Wilkins, A.L., \& Ouchi, W.G. (1983). Efficient cultures: Exploring the relationship between culture and organisational performance. Administrative Science Quarterly, $28,468-481$.

Wilson, A.M. (2001) Understanding organisational culture and the implications for corporate marketing. European Journal of Marketing, 35 (3/4): 353-367.

Xenikou, A., \& Furnham, A. (1996). A Correlational and factor analytic study of four questionnaire measures of organisational culture. Human Relations, 49, 349-371. 